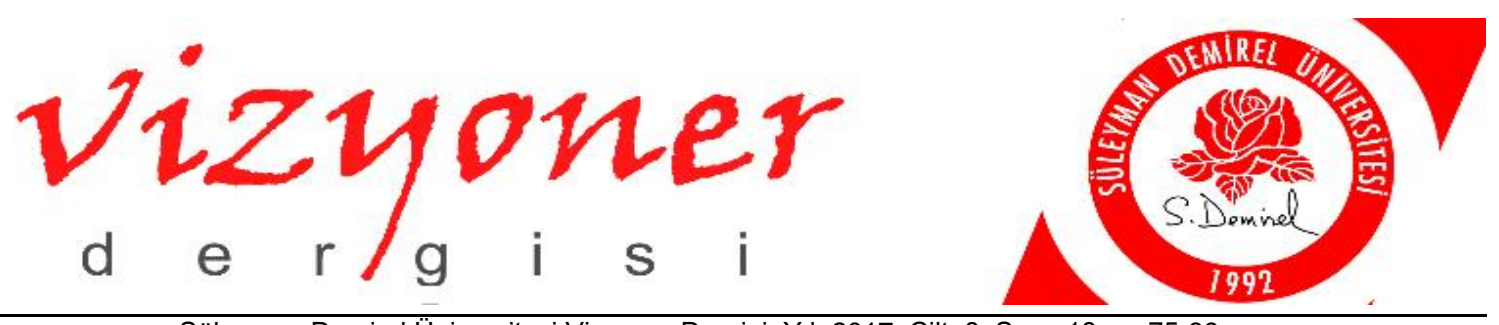

Süleyman Demirel Üniversitesi Vizyoner Dergisi, Yıl: 2017, Cilt: 8, Sayı: 18, ss.75-89.

\title{
BİREY ÖRGÜT UYUMUNUN DUYGUSAL EMEK ÜZERINNDEKİ ETKILLERI: HEMŞİRELER ÜZERİNE GÖRGÜL BİR ARAŞTIRMA
}

\section{THE EFFECTS OF PERSON ORGANIZATION FIT ON EMOTIONAL LABOR: AN EMPIRICAL RESEARCH ON NURSES}

Yrd. Doç. Dr. Mustafa KESEN ${ }^{1}$

Öz

Bu çalışmanın amacı birey örgüt uyumu ile duygusal emek boyutları (yüzeysel davranış, derinden davranış ve doğal duygular) arasındaki etkileşimleri ortaya koymaktadır. Çalışma amacı doğrultusunda Çanakkale'de çalışan 355 hemşire üzerinde anket uygulaması yapılmıştır. Araştırmada öne sürülen hipotezler basit doğrusal regresyon modelleri ile test edilmiştir. Elde edilen sonuçlara göre birey örgüt uyumu derinden davranış ve doğal duyguları olumlu yönde anlamlı bir şekilde etkilemektedir. Fakat birey örgüt uyumu ile yüzeysel davranış arasında anlamlı bir ilişki bulunmamaktadır. Çalışma bulguları kapsamında yönetici ve araştırmacılar için öneriler geliştirilmişstir.

Anahtar Kelimeler: Birey Örgüt Uyumu, Duygusal Emek, Hemşireler, Sağlık Hizmetleri.

JEL Sinıflandırma Kodları: M12, M51, M54, O15.

\begin{abstract}
The aim of this study is to reveal the interactions between person organization fit and dimensions of emotional labor (surface acting, deep acting and genuine emotions). In parallel with the goal of study, a survey was conducted among 355 nurses working in the province of Çanakkale. The hypotheses proposed were analyzed with simple linear regression models. According to the results, person organization fit significantly and positively affects deep acting and genuine emotions. Surface acting, on the other hand, is not significantly related to person organization fit. Proposals have been developed for managers and researchers within the scope of the results.
\end{abstract}

Keywords: Person Organization Fit, Emotional Labor, Nurses, Healthcare Services.

JEL Classification Codes: M12, M51, M54, O15.

\section{GíRiş}

Sağlık hizmetlerinin hastalara daha iyi fiziksel ve psikolojik şartlarda verilebilmesi için hasta odaklı uygulamalara verilen önem gün geçtikçe artmaktadır. Sağlık sektörü, hizmet verilen hedef kitleye fiziksel yakınlığın yoğun olduğu sektörlerden biridir (Price vd., 1995). Özellikle hemşireler, hasta ile yoğun bir iletişim içerisinde olan bir meslek grubudur ve sağlık kurumlarının başarıya ulaşmasında çok önemli rollere sahiptirler (Wang ve Chang, 2016: 153). Bireylerle fiziksel yakınlığın ise duygusal etkileşimi beraberinde getireceği açıktır. Çünkü fiziksel mesafe azaldıkça iletişim kuranlar, bilinçli veya bilinç dışı olarak hem kendileri daha yoğun bir duygusal etkileşim sürecine girmeyi tercih etmekte hem de karşı tarafin duygusal tepkilerine yoğunlaşmaktadırlar. Bu açıdan bakıldığında hasta memnuniyetinin sağlanmasında hemşirelerin duygusal etkileşimlerinin kalitesi önemli rol oynamaktadır. Bu sebeple duygusal emeğin hangi faktörlerden nasıl etkilendiğinin araştırılması, günümüz modern örgütlerinin görevlerinin önemli bir parçası haline gelmektedir.

Adnan Menderes Üniversitesi, Söke İşletme Fakültesi, İnsan Kaynakları Yönetimi Bölümü, m_kesen@hotmail.com 
Çalışanın, gününün önemli bir kısmını birlikte geçirdiği örgütüyle arasında kurduğu psikolojik bağ ve yakınlık, bedensel ve zihinsel emeğin yanında duygusal emeğinin de verimini etkileyecektir. Çalışan örgütünün adalet, hakkaniyet, dürüstlük gibi değerlerini ne kadar paylaşıyorsa, kişisel duygularını da o ölçüde iş performansını arttırmak için kullanabilecek ve yönetebilecektir. Bu sebeple, çalışan ve örgütün değerleri arasındaki algılanan uyumu ifade eden birey örgüt uyumu ile duyguların örgütün istediği şekilde yönlendirilmesini ifade eden duygusal emek kavramı arasındaki ilişkinin araştırılması gerekmektedir. Nitekim Thomassen (2012) çalışmasında, duygu düzenleme stratejileri ile birey örgüt uyumu arasındaki yakın ilişkiden bahsetmektedir. Bu noktadan hareketle bu çalışmanın amacı, birey örgüt uyumu ile duygusal emek stratejileri arasındaki ilişkiyi uygulamalı bir araştırma ile ortaya koymaktır. İlgili literatürde duygusal emeğin bir süreç mi yoksa bir sonuç mu olduğuna yönelik tartışmalar bulunmaktadır. Örneğin Hochschild (1989) ve Grandey (2000) duygusal emeği bir süreç olarak nitelendirirken Ashforth ve Humphrey (1993) sonuç olarak değerlendirmektedir. Bu çalışmada ise duygusal emek bir sonuç olarak ele alınmakta ve bu sonucun birey örgüt uyumu tarafından şekillendirileceği varsayılmaktadır. Birey ile örgüt arasında çalışan tarafından algılanan benzeşim arttıkça, çalışanların daha fazla duygusal emek sarf edecekleri düşünülmektedir.

Hem birey örgüt uyumu hem de duygusal emek literatürüne katkıda bulunulacağı düşünülen bu çalışmada öncelikle konu ile ilgili literatür taramasına yer verilmiş, ardından çalışmanın metodolojisi üzerinde durulmuş ve son olarak sonuçlar yorumlanmıştır. Elde edilen bulguların yöneticilere, araştırmacılara ve sağlık hizmeti verenlere önemli ipuçları sunacă̆ı düşünülmektedir.

\section{KAVRAMSAL ÇERÇEVE}

\subsection{Birey Örgüt Uyumu}

Çalışanların işe ve işyerine uyum sağlaması, günümüz modern örgütlerin temel hedeflerinden biridir. Yaşadığı ortama ayak uydurabilen ve yaşadığı ortamı benimseyen bireylerin kendilerine, örgütlerine ve topluma yapacakları katkı daha da artacaktır. Nitekim işletmelerde insan kaynakları birimleri ve birim yöneticileri, işe alım sürecinde örgüte uyum sağlayabilecek bireyleri seçmeye özen göstermektedirler. Aynı şekilde işe yeni alınan bireylere oryantasyon programları düzenlenmekte ve çalışanların sosyalleşme sürecini başarıyla geçmeleri hedeflenmektedir. Personel eğitim sürecinde bireyin işyerine uyumunu sağlayacak prosedürler takip edilmekte ve performans değerlendirmede bireyin örgütüne ve çevresine uyum sağlayabilme derecesine dikkat edilmektedir. Kariyer yönetimi faaliyetlerinde örgüte uyum sağlayanların yükseltilmesinin daha uygun olacağ düşünülmekte ve örgüte uyum sağlayanların iş güvenliğine daha fazla önem vereceği varsayılmaktadır. Bu ve buna benzer birçok insan kaynakları faaliyetinde birey örgüt uyumunun sağlanmaya çalışıldığını söylemek mümkündür. Çünkü birey örgüt uyumu, örgütsel etkinliği sağlama (Goodman ve Svyantek, 1999) ve daha olumlu iş çıktıları elde etmede (Afsar ve Badir, 2016) önemli rol oynamaktadır.

Chatman (1989)'e göre birey-örgüt uyumu, örgüt çalışanlarının kendi bireysel değerleri ve normları ile örgütünün değerleri ve normları arasındaki uyumluluktur. Bireyler ve örgütler, bilinçli veya bilinç dışı bir şekilde bu uyumu sağlayacak işyeri veya kişi seçimi yapmaya özen gösterirler. Çünkü böyle bir durumda ihtiyaçlar karşılıklı olarak daha kolay giderilebilecektir (Kristof-Brown vd., 2005).

Kendini sınıflandırma kuramına göre (Self-Categorization Theory), grup içindeki paylaşılan kültüre verilen kişisel destek, grup ile özdeşleşmeyi kolaylaştırmaktadır (Turner vd., 1987). Bireylerin inanç, değer ve tutumları ile örgüt kültürü arasındaki algılanan benzerlik, birey örgüt uyumunun temel özelliği olarak değerlendirilmektedir (Bowen vd., 1991; Schneider, 1987). Grup ile benzeşmek, hem bireylerin sosyal ihtiyaçlarını giderebilmelerine olanak sağlamakta hem de grubun ve içinde bulunulan örgütün çıkarlarını savunmayı kolaylaştırmaktadır. Örgütün değerleri ile çalışanların değerleri arasındaki algılanan uyumsuzluk ise birey örgüt uyumunun düşük olduğunu göstermektedir (Ostroff vd., 2005). Buradan hareketle kişi örgüt uyumu düşüncesinin temelinde örgütlerin ve bireylerin kendilerine uygun olanı seçmesi ve uyumsuzluk durumunda tek veya çift taraflı olarak çalışan ve örgüt ilişkisinin sona ermesi isteğinin yattığını söylemek mümkündür.

Literatürde birey örgüt uyumunun bireysel ve örgütsel sonuçlarına dair birçok araştırmanın yapıldı̆̆ görülmektedir. Bazı sonuçlar incelendiğinde; birey örgüt uyumu stresi (de Lara, 2008), değişime karşı direnci (Castka vd., 2001) ve işten ayrılmaları (Hoffman ve Woehr, 2006; Sipahi ve Kesen, 2016) azaltmakta, iş doyumu (Meglino vd., 1989), örgütsel vatandaşlık davranışı ve algılanan örgütsel desteği (Afsar ve Badir, 2016), performansı (Deng vd., 2015), işe bağlılığı (Silverthorne, 2004) ve örgüte bağlılığı (Chatman, 1989) 
arttırmaktadır. Birey örgüt uyumsuzluğu ise çalışanlarda stresi, çatışmaları, örgüte yabancılaşmayı ve devamsızlığı, örgütlerde de işgören devrini arttırmaktadır (Vilela vd., 2008; Yücel ve Çetinkaya, 2016).

Kristof (1996)'a göre bireysel ve örgütsel özellikler arasındaki benzeşim uyumu arttırmaktadır. Örgüt kültürü, örgüt iklimi, örgütsel değer ve amaçlar ile örgütsel normlar örgütsel özellikler kapsamında değerlendirilirken kişisel değerler, amaçlar, kişilik ve yetenekler de bireysel özellikler kapsamında değerlendirilmektedir. Bu özellikler ne kadar örtüşüyorsa, birbirini tamamlayan ve sinerji oluşturan bir ahenk ve uyum ortaya çıkmaktadır.

Birey örgüt uyumunun nasıl sağlanacağı birçok çalışmaya konu olmuştur. Çalışan ve örgütün karşılıklı olarak birbirinin çıkarlarına hizmet etmesi uyumu arttırmaktadır. Birey örgüt uyumunu sağlayarak örgütler karlılıklarını, sürdürülebilirliklerini arttırma ve pazar liderliğine oynamayı hedeflerken çalışanlar kendilerine anlamlı gelen bir işte çalışmayı, takdir edilmeyi, terfi almayı, işyerinde mutluluğu, çalışma arkadaşları ile olumlu ilişkiler geliştirmeyi ve yaşam kalitelerini arttırmayı hedeflemektedirler (Sutarjo, 2011:228). Birey örgüt uyumunu sağlamak için ise sürecin en başında iş ilanlarında şirket değerleri ve kültürel özellikleri vurgulanmalıdır. Diğer taraftan bireyin yetenek ve değerlerinin analiz edilmesi ve ona uygun işlere yerleştirilmesi gerekmektedir. Yeteneklerine uygun işte istihdam edilen personelin ise örgütünü daha fazla önemseyeceği ifade edilmektedir (Carless, 2005). Mevcut kültürel değerlere uyum sağlayamayan bireylerin örgütten uzaklaştırılması da geride kalanların örgüte uyumunu kolaylaştırabilecektir (Sathe, 1985). Fakat örgüt değerlerini benimsemeyen yetenekli bireylerle birlikteliği sonlandırma kararı almadan önce fayda maliyet analizi muhakkak yapılmalıdır (Gibson vd., 2003). İnsan kaynaklarının eğitiminde, çalışan örgüt uyumunu arttıracak en iyi eğitim programlarının seçilmesi ve uygulanmasına dikkat edilmelidir (Autry ve Wheeler, 2005). Birey ve grupların farklılıklara saygı duymaya, karşı tarafın düşüncesine değer vermeye ve birlikte yaşamaya yönlendirilmesi gerekmektedir. Dolayısıyla benzer olmayan grup ve bireylerle işte uyum sağlama hedefiyle çalışanlara duyarlılık eğitimleri de verilebilir. Birey örgüt uyumunu sağlamada önemli görevlerden biri liderlere düşmektedir (Van Vianen vd., 2007). Liderlerin örgütün bireye, bireyin örgüte uyum sağlama noktasında katalizör görevi üstlendiği ifade edilmektedir (Sutarjo, 2011). Örneğin Li (2007) tarafindan yapılan çalışmada etkileşimci ve takım çalışması odaklı liderliğin birey örgüt uyumuna anlamlı etkisi olduğu bulgulanmıştır. Birey örgüt uyumunu sağlamada bireylere de bazı görevler düşmektedir. İş başvurularında bireyler sadece parası için çalışabileceği işlere başvurmamalı, aynı zamanda başvurulan kurumun değerleri ile kişisel değerler arasında bir yakınlık veya benzerlik aramalıdır. Benzer şekilde bireyler kendi değer ve algılarını kritiğe tabi tutmalı, yanlış bir tutum içinde olduğunu fark ettiklerinde örgüt yararına değer ve tutumlarını güncelleyebilmelidirler. Özetle birey örgüt uyumunu sağlamada örgütlere, liderlere ve bireylere birtakım görevler düşmekte ve bu uyumu arttırma noktasında karşılıklı sorumluluk almak gerekmektedir.

Birçok faydasından bahsedilen birey örgüt uyumunun bazı dezavantajları da beraberinde getirebileceği değerlendirilmektedir. Gereğinden fazla uyum, örgütlerin farklı durumlara uyumunu sağlayacak esnekliğe zarar verebilir ve piyasa koşullarına uygun reaksiyon göstermeyi sağlayan bakış açılarındaki çeşitliliği azaltabilir (Verquer vd., 2003). Fonksiyonel çatışmaların azalması, rahatlık ve rehavetin ortaya çıkması ve tarafları diri tutacak rekabetin zayıflaması, karşılaşılabilecek bazı durumlardandır. Diğer taraftan fazla uyum, örgütsel gelişimi sağlayacak eleştirel bakışı zayıflatabilir ve değişiklik taleplerini sorgulamanın önüne geçebilir. Aynı inanç ve değerlere sahip olanlar, örgütü yavaşlatan benzer kör noktalara da sahip olabilmektedirler (Cheng, 2014). Homojenliğin fazla olduğu gruplarda örgütün yenilik kapasitesi düşebilmektedir (Schneider vd., 1995). Benzer şekilde liderlerin uyuma gereğinden fazla vurgu yapması, muhalif düşüncelere ve kişilere işletmede yer olmadığı şeklinde algılanabilir. Böyle bir durumda aykırı düşüncesi olanlar fikirlerini beyan etmekten kaçınabilirler ve muhalif ama yetenekli bireyler de örgütlerinden ayrılabilirler.

\subsection{Duygusal Emek}

Duygusal emek kavramını kapsamlı bir şekilde ilk defa gündeme getirdiği ifade edilen Hochschild (1983) duygusal emeği; "müşterilere iyi hizmet vermek için çalışanların müşterilerle etkileşim içindeyken, duygularını yönetmeleri ve bu yönetme sırasında gösterdikleri emek" şeklinde tanımlamaktadır (Öz, 2007:3). İşte profesyonelliğin önemli bir parçası olan duygusal emek, müşterilerde genellikle olumlu duygular uyarmayı ve böylece tatmin olmuş müşterilere sahip bir organizasyon hedefine ulaşmayı içermektedir.

Duygusal emek, iş ile duygu gösterimlerinin uyumlaştırılmasını, yani işe uygun duyguları göstermeyi veya işe uygun olmayan duyguları gizlemeyi ifade etmektedir (Diefendorff vd., 2005). Örneğin çalışanlardan müşterilere karşı coşku, ilgi ve neşe gibi olumlu duyguların gösterilmesi istenirken öfke, düşmanlık, sıkıntı ve keder gibi olumsuz duyguları bastırmaları beklenmektedir (Scott ve Barnes, 2011). Olay ve durumları başkalarının 
gözünden anlama yeteneği gerektiren duygusal emek ile ilgili araştırmalar, işte başarılı olmak için bedensel ve zihinsel çabanın yeterli olmadığını ortaya koymaktadır (Lee vd., 2012: 5). Özellikle sağlık, eğitim, perakende, ulaşım vb. hizmet yoğun alanlarda faaliyet gösteren işletme çalışanlarının duygusal çabaları, çalışan ve örgüt performansı açısından önemlidir. Nitekim bazı uygulamalı araştırmalardan elde edilen veriler, duygusal emeğin örgütsel performans1 arttırabileceğini göstermektedir (Meier vd., 2006: 900). Diğer taraftan hissedilen duygular ile istenen duygular arasında sıkışan bireylerin kendilerine ve çevrelerine yabancılaşabileceği, özgünlüklerini kaybedebileceği ve yoğun stres yaşayabilecekleri de ifade edilmektedir (Hochschild, 1983).

Duygusal ifadelerin biçimlendirilmesi ve duyguların yönetilmesi duygusal emeğin parçasıdır (Roh vd., 2016: 45). Brotheridge ve Grandey (2002) duygusal emeği, duyguların örgüt tarafından yönetilmesi ve duyguların çalışanlar tarafından yönetilmesi olmak üzere ikiye ayırmaktadırlar. İş ile ilgili özelliklere odaklanan ilki "iş odaklı duygusal emeğil" ifade ederken çalışanların öz yönetimini vurgulayan ikincisi "çalışan odaklı duygusal emeği”" belirtmektedir. İş odaklı duygusal emekten kasıt örgütlerin çalışanlarını duygusal çaba göstermeye itmeleridir. Hsieh vd. (2016) bunu iş gerekleri olarak ele almış ve duygusal emek gerekleri şeklinde adlandırmışlardır. Bu kapsamda örgütler iş analizi sürecinde her bir işte müşterilere gösterilmesi ve gösterilmemesi gereken duyguları tespit etmekte ve analiz sonuçlarına dayanarak iş başvuru kriterlerini oluşturmaktadırlar. Çalışan odaklı duygusal emek ise bireylerin işlerini yaparken kendileri tarafindan ortaya konan çabadır. Bu ise Hsieh vd. (2016) tarafından duygusal emek stratejileri şeklinde ele alınmaktadır. Literatürde duygusal emek araştırmalarında daha çok çalışan odaklı duygusal emek işlenirken, iş odaklı duygusal emeğe değinen çalışmalar da bulunmaktadır (örn. Schaubroeck ve Jones, 2000).

Çalışanlar tarafından harcanan duygusal emek yüzeysel davranış (surface acting) ve derinden davranış olmak (deep acting) üzere ikiye ayrılmaktadır (Hochschild, 1983). Yüzeysel davranış duyguyu içselleştirmeden, sadece verilen tepkinin ayarlanmasını vurgularken derinlemesine düşünerek davranma ise bireyin hissettiği duyguları kontrol edip, göstermekle yükümlü olduğu duyguyu bizzat yaşayarak içselleştirmeye çalışmasını ifade etmektedir (Gülova vd., 2013:44). Bir otel personelinin kendini endişeli ve huzursuz hissettiği bir zamanda gelen müşteriyi güler yüzle karşılamaya çalışması yüzeysel davranışa örnek olarak verilebilirken (Kızanlıklı ve Ünlüönen, 2016: 505) çalışanın moralini düzeltip daha neşeli davranma yönünde kendini motive etmeye çalışması derinden davranışa örnek olarak verilebilir. Hochschild (1983) derinden davranışı aktif derinden davranış (active deep acting) ve pasif derinden davranış (passive deep acting) olmak üzere ikiye ayırmıştır. Aktif derinden davranışta çalışan, rol gereklerini yerine getirebilmek için, içsel duygularını ve dışa karşı duygu gösterimlerini bilinçli bir şekilde manipüle etmektedir. Pasif derinden davranışta ise çalışan, bilinçli olmadan kendi özgünlüğünü koruyarak istenilen duyguları göstermeye yönelmektedir.

Ashforth ve Humphrey (1993) bireylerin yüzeysel ve derinden rol yapmalarına gerek kalmadan, gerçek duygu durumlarıyla hareket edebileceklerini belirtmiş ve Hochschild'in çift boyutlu yaklaşımına ek olarak doğalsamimi duyguları (spontaneous and genuine emotions) üçüncü boyut olarak eklemişlerdir (Beğenirbaş ve Turgut, 2014). Böylece çalışan diğer boyutlarda olduğu gibi duygularını değiştirme yönünde herhangi bir zorlama hissetmeyecek ve doğal bir şekilde davranabilecektir (Polatc1 ve Özyer, 2015: 134). Örneğin bir hemşire yaralanmış ve acı çeken bir çocuğa sahte duygular göstermek zorunda değildir ve içinden geldiği şekliyle üzüntüsünü ifade edebilir (Ashforth ve Humphrey, 1993: 94). Kruml ve Geddes (2000) samimi duyguları Hochschild (1983)'in tarif ettiği pasif derinden davranışla ilişkilendirmektedir. Diğer taraftan Diefendorff vd., (2005) işletmelerde samimi duyguların yüzeysel ve derin davranıştan daha fazla kullanıldığını belirtmektedirler (Kızanlıklı ve Ünlüönen, 2016: 505).

Çalışanların duygularını, gerçekleştirdikleri işlere uygun hale getirmesi ile ilişkilendirilen (Durgut ve Kahya, 2015: 360) duygusal emek, birlik ve beraberlik duygusunun artması (Shuler ve Sypher, 2000), özgüven artış1 ve olumlu psikolojik durum, düşük stres (Conrad ve Witte, 1994), özsaygı ve iş tatmininde artış (Strickland, 1992; Wharton, 1993), iş verimliliğinde artış (Connellan ve Zemke, 1993) gibi bazı olumlu iş çıktıları ile ilişkilendirilmektedir (Kruml ve Geddes, 2000: 13). Diğer taraftan tükenmişlik (Tolich, 1993; Wharton, 1993), zayıf benlik saygısı, depresyon, sinizm, role yabancılaşma, kendine yabancılaşma (Ashforth ve Humphrey, 1993; Fineman, 1993; Seeman, 1991), stres (Sharrad, 1992) ve duygusal sapma (Fineman, 1993; Tolich, 1993) gibi istenmeyen sonuçları da beraberinde getirebilmektedir (Kruml ve Geddes, 2000: 12). Ayrıca, derinden davranışın yüzeysel davranıştan daha fazla olumlu sonuçlar doğurduğu ifade edilmektedir (Mesmer-Magnus vd., 2011; Scott vd., 2012: 905; Ko ve Jeng, 2016). Fakat derinden davranış yüzeysel davranıştan daha fazla duygusal çaba gerektirdiğinden çalışanlar genellikle daha az çaba harcayacakları yüzeysel davranışlara yönelmektedirler (Wong ve Wang, 2009). 


\subsection{Birey Örgüt Uyumu ile Duygusal Emek İlişkisi}

Rayner ve Espinoza (2015) duygusal çabanın bireyin çevresine uyum sağlaması ile ilişkili olabileceğini ifade etmektedirler. Benzer şekilde Lauver ve Kristof-Brown (2001) da hizmet sektöründe birey ile iş çevresi uyumunun bireyin tutum ve davranışlarını etkileyeceğini belirtmektedirler. Örneğin duygusal emeğin bireyin işine uyumunu sağladığı bildirilmektedir (Pierce ve Gardner, 2004; Xanthopoulou vd., 2007). Dolayısıyla bu bireylerin işyerinde gereken çabayı daha rahat gösterecekleri ve müşterilere karşı daha az yüzeysel davranışlar sergileyebilecekleri ifade edilebilir (Babakus vd., 2009; Smith vd., 2012). Fakat kişilik, beklenti ve değer yargıları örgütünkiyle örtüşmeyen bireyler ise sahte duygu gösterimlerinde bulunacaklardır (Mishra vd., 2012). Çünkü örgüt değerlerine uyum sağlayamamış çalışanlar, örgüt tarafından istenilen duyguları göstermenin kendi işleri olmadığını düşünebilmektedirler. Buradan hareketle çalışmanın ilk hipotezi şöyle geliştirilmiştir:

Hipotez 1: Birey örgüt uyumu duygusal emeğin yüzeysel davranış boyutunu olumsuz yönde etkilemektedir.

Bireysel ve örgütsel değerler arasındaki farklar azaldıkça çalışanların daha fazla duygusal emek sarf edecekleri düşünülmektedir. Örgütüyle kendini özdeşleştirebilen bireyler örgütsel kurallara daha kolay adapte olabilecek, duygu ve davranışlarını daha kolay düzenleyebilecek, böylece örgütün arzuladı̆̆ı duygu gösterimlerini daha kolay sergileyebilecek ve etkin bir şekilde duygusal çaba göstereceklerdir (Zeng vd., 2014). Örgütü ile kendisi arasında büyük bir birliktelik gören çalışanların sahte duygu gösterimleri yerine örgüt yararına derinden rol yapacakları düşünülmektedir. Örgütsel kimlik ile kendi kimliğini uyumlaştırabilen bireyler örgüt yararına çalışmayı önemseyecek (Van Knippenberg ve Sleebos, 2006) ve örgütüyle ortak kadere inanacaklardır (Ashforth ve Mael, 1989) çünkü örgütün yararına olan birçok şey kendi çıkarlarıyla örtüşecektir (Mishra vd., 2012). Bu potansiyel ilişkiler 1şı̆̆ında ilgili hipotez şöyle geliştirilmiştir:

\section{Hipotez 2: Birey örgüt uyumu duygusal emeğin derinden davranış boyutunu olumlu yönde etkilemektedir.}

Çalışan ve örgütün uyumu sağlandığında muhtemel sonuçlardan bazıları bireylerin kendilerine ilişkin olumlu benlik algılarına ulaşmaları, işyerinde daha şeffaf olmaları ve daha samimi davranmalarıdır. Örneğin birey örgüt uyumu sağlandığında çalışanlar daha fazla açıkça konuşma davranışı sergilemektedirler (Pekdemir vd., 2013). Uyum arttıkça çalışanlar yapay davranışlar sergilemekten hoşlanmayacak ve doğallığa daha fazla meyledebileceklerdir. Dolayısıyla çalışmanın son hipotezi şöyle kurgulanmıştır:

Hipotez 3: Birey örgüt uyumu duygusal emeğin doğal duygular boyutunu olumlu yönde etkilemektedir.

Literatür taraması sonucunda ilgili değişkenler arasında yakın ilişkiler olabileceği gözlemlenmektedir. Buradan yola çıkarak Şekil 1'deki araştırma modeli oluşturulmuştur.

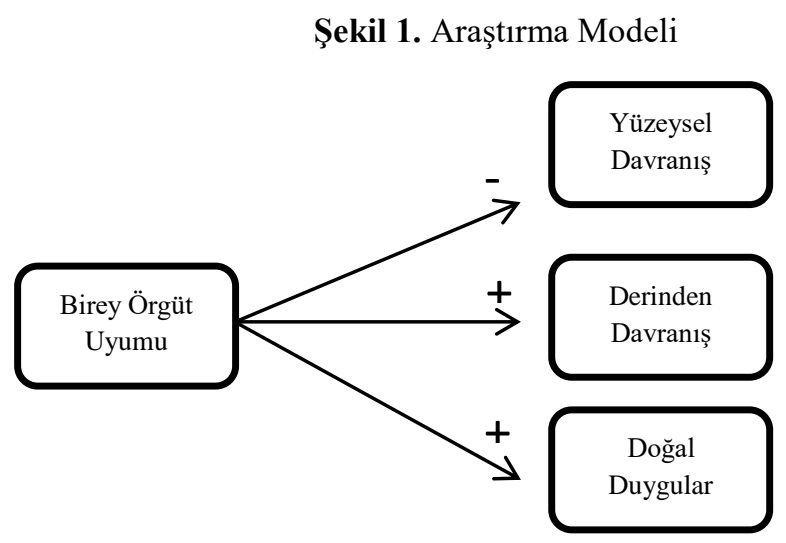

\section{YÖNTEM}

\subsection{Araştırmanın Örneklemi}

Duygusal emek, özellikle hizmet sektöründe çalışanların performansında etkili olan bir kavramdır. Hastane çalışanları da hastalarla iletişim kurarken duygularını kontrol etmek durumundadırlar. Örneğin hemşireler hastalara bakım hizmeti verirken fiziksel ve zihinsel olarak gösterdikleri emeğe ek olarak önemli ölçüde duygusal emek sergilemektedirler (Altuntaş ve Altun, 2015:37). Bu sebeple birey örgüt uyumunun duygusal 
emeğe etkisinin hemşireler üzerinde yapılan bir araştırmayla test edilmesinin daha sağlıklı sonuçlar ortaya koyacağı düşünülmektedir. Bu amaçla 2016 yılında Çanakkale il sınırları içerisindeki hastanelerde çalışan hemşireler üzerinde araştırma yapılmıştır. Çanakkale Valiliği'nden (2016) elde edilen bilgiye göre Çanakkale'de çalışan toplam hemşire sayısının 1880 olduğu tespit edilmiştir. Araştırma için gerekli örneklem sayısının tespiti için $n=\left(N . t^{2}\right.$.p.q)/(d ${ }^{2}$.(N-1) $+t^{2}$.p.q) formülünden yararlanılmıştır (Yazıcığlu ve Erdoğan, 2004). Elde edilen sonuca göre örneklem sayısı 319 olmalıdır $(\mathrm{N}=1880 ; \mathrm{t}=1,96 ; \mathrm{p}=0,5 ; \mathrm{q}=0,5 ; \mathrm{d}=0,05)$. Tesadüfi örnekleme yönteminin kullanıldığı bu araştırmada ise 355 kişiden anket yoluyla veriler toplanmıştır.

Tablo 1. Demografik Özellikler

\begin{tabular}{|c|c|c|c|}
\hline & & Sayt & Yüzde \\
\hline \multirow{2}{*}{ Cinsiyet } & Kadın & 220 & 62 \\
\hline & Erkek & 135 & 38 \\
\hline \multirow{6}{*}{ Yaş } & $20-25$ yaş aralığ & 44 & 12 \\
\hline & $26-30$ yaş aralığ & 80 & 23 \\
\hline & $31-35$ yaş aralığ & 62 & 17 \\
\hline & $36-40$ yaş aralığ 1 & 91 & 26 \\
\hline & $41-50$ yaş aralığ 1 & 75 & 21 \\
\hline & 50 yaş üzeri & 3 & 1 \\
\hline \multirow{2}{*}{ Medeni Durum } & Evli & 324 & 91 \\
\hline & Bekar & 31 & 9 \\
\hline \multirow{3}{*}{ Mezuniyet } & Önlisans & 104 & 30 \\
\hline & Lisans & 183 & 51 \\
\hline & Yüksek Lisans & 68 & 19 \\
\hline \multirow{6}{*}{ Mesleki Kıdem } & $0-3$ yil & 54 & 15 \\
\hline & 4-6 y1l & 46 & 13 \\
\hline & $7-10 \mathrm{y} 1 \mathrm{l}$ & 51 & 14 \\
\hline & $11-15$ y1l & 84 & 24 \\
\hline & $16-20 \mathrm{y} 11$ & 56 & 16 \\
\hline & 20 yıldan fazla & 64 & 18 \\
\hline
\end{tabular}

Ankete katılan çalışanların demografik özellikleri Tablo 1'de gösterilmiştir. Katılımcıların \%62'si kadın iken \%38'i erkektir. Çalışanların \% 26'sı 36-40 yaş aralığında olup sadece \% 1'i 50 yaş üstündedir. Medeni durum açısından incelendiğinde ankete katılanların \% 91'i evlidir. Katılımcıların \%51'i lisans mezunu iken \% 24'ü 1115 yıldır sağlık sektöründe çalışmaktadır.

\subsection{Veri Toplama Araçları ve Veri Analiz Yöntemi}

Anketlerde soruların 5'li Likert şeklinde (1=Kesinlikle katılmıyorum, 5=Kesinlikle katılıyorum) cevaplanması istenmiştir. Çalışmada toplanan veriler, araştırma kurgusu doğrultusunda SPSS programı kullanılarak analiz edilmiştir.

Birey-Örgüt Uyumu Ölçeği: Ankete katılanların birey örgüt uyumu algılarını ölçmek için Akbaş (2010)'ın çalışmasından yararlanılmıştır. Netemeyer vd. (1997: 96) tarafından geliştirildiği aktarılan algılanan kişi-örgüt uyumu ölçeği, dört maddeden oluşmaktadır ve tek boyutludur.

Duygusal Emek Ölçeği: Duygusal emek ölçeği için Basım ve Beğenirbaş (2012)'ın çalışmasından yararlanılmıştır. İlgili ölçeğin Diefendorff vd. (2005) tarafından, Grandey (2003) ve Kruml ve Geddes'in (2000) duygusal emek ölçeklerinin bazı maddelerinin alınarak uyarlanması ve bazı maddelerin ise geliştirilmesiyle oluşturulduğu ifade edilmiştir. Ölçek toplamda 14 madde ve 3 alt boyuttan oluşmaktadır. Yüzeysel rol yapma boyutu 6 , derinden rol yapma 4 ve doğal duygular boyutu 3 madde ile ölçülmüştür.

Veri toplama araçlarından elde edilen verilerin normal dağılıma uygunluğu basıklık ve çarpıklık testi ile test edilmiştir. Basıklık ve çarpıklık değerlerinin -1 ile +1 arasında olması arzulanmaktadır. Bununla birlikte -2 ile +2 arasındaki değerlerin de kabul edilebilir sınırlar içerisinde olduğu ifade edilmektedir (Kunnan, 1998; Karaatlı 2006). Ölçeklerdeki maddelerin basıklık skorlarının -1,599 ile 1,021 arasında, çarpıklık skorlarının ise -0,122 ile 1,216 arasında olduğu gözlemlenmiştir. Buradan hareketle verilerin normal dağılıma sahip olduğu ifade edilebilir. 
Araştırma verilerinde otokorelasyon ve çoklu bağlantı problemi olup olmadığını test etmek amacıyla DurbinWatson testi yapılmış ve VIF (Variance Inflation Factor) değerlerinden yararlanılmıştır. 1,5 ile 2,5 arasında çıkması beklenen Durbin-Watson katsayılarının (Öztürk, 2006: 264) bu çalışmada 2,087 ile 2,310 arasında değerler aldığı görülmüştür. Ayrıca, çoklu doğrusal bağlantı probleminin olmaması için VIF değerlerinin 10'dan küçük olması gerektiği ifade edilmektedir (Hair, Bush ve Ortinau, 2003). Bu çalışmada VIF değerleri 10’un altında bulunmuştur. Böylece veri setinde otokorelasyon ve çoklu doğrusal bağlantı probleminin olmadığı sonucuna varılmıştır.

\subsection{Faktör Analizi}

Araştırmada kullanılan ölçeklerin geçerliliğini belirlemek için açımlayıcı faktör analizinden yararlanılmıştır. Tablo 2'de birey örgüt uyumu ölçeğine ilişkin faktör analizi sonuçları gösterilmiştir. İlgili maddeler toplam varyansın \% 87,3'ünü açıklamaktadır. "Bu kurumun değerleri ile kişisel değerlerimin uyumlu olduğunu düşünüyorum.” ifadesi ölçekteki maddelere örnek olarak verilebilir.

Tablo 2. Birey Örgüt Uyumu Ölçeği Faktör Analizi Sonuçları

\begin{tabular}{ll}
\hline Birey Örgüt Uyumu 1 &, 838 \\
Birey Örgüt Uyumu 2 &, 972 \\
Birey Örgüt Uyumu 3 &, 934 \\
Birey Örgüt Uyumu 4 &, 986 \\
\hline
\end{tabular}

Tablo 3'te duygusal emek ölçeğine ilişkin faktör analizi sonuçları verilmiştir. Yüzeysel rol yapma boyutuna ait maddelerden ikisi başka faktör altında toplandığından ölçekten çıkarılmıştır. Orijinal ölçekteki üç alt faktör yapısıyla tutarlılık gösteren ilgili ölçeğin faktör yüklerinin 0,719 ile 0,955 değerleri arasında olduğu görülmektedir. "Hastalarıma gerçek hissettiğim duygulardan farklı duygular sergilerim.” yüzeysel davranış; "Hastalara göstermem gereken duyguları hissedebilmek için elimden geleni yaparım." derinden davranış ve "Hastalara gösterdiğim duygular o an hissettiklerimle aynıdır." doğal duygular boyutundaki ifadelere örnek olarak verilebilir. Derinden davranış, yüzeysel davranış ve doğal duygular boyutlarının toplam varyansı açıklama düzeyleri sırasıyla \%59.7, \% 29.8 ve \%5.4 olarak hesaplanmıştır. Dolayısıyla ölçeğin tümü toplam varyansın \%95.1'ini açıklamaktadır.

Tablo 3. Duygusal Emek Ölçeği Faktör Analizi Sonuçları

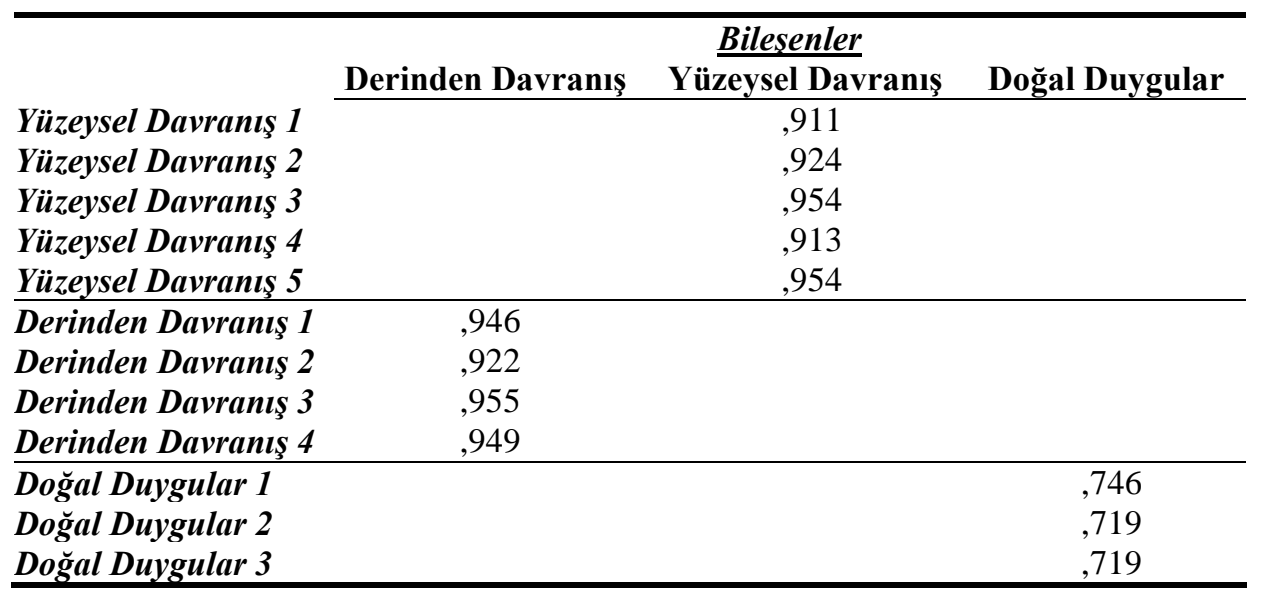

\subsection{Güvenirlik Analizi}

Faktörlerin güvenirlik (iç tutarlılık) katsayıları Cronbach's Alfa değeri ile hesaplanmıştır. Birey örgüt uyumu ölçeği için ,949 değeri bulunmuştur. Duygusal emek ölçeğinin yüzeysel rol yapma boyutu için ,967; derinden rol yapma için ,985 ve doğal duygular boyutu için ,992 değerleri bulunmuştur. Genel olarak duygusal emek ölçeği için ise ,815 değeri hesaplanmıştır. Tezbaşaran (1996) araştırmalarda kullanılabilecek ölçme araçları için öngörülen güvenirlik düzeyinin ,70 olduğunu ifade etmektedir. Dolayısıyla çalışmada kullanılan ölçeklerin güvenirlik değerlerinin kabul edilebilir sınır olan ,70'in üzerinde olması, ölçeklerin güvenirliğini ortaya koymaktadır. 


\subsection{Korelasyon Analizi}

Araştırmadan elde edilen verilerin ortalamaları, standart sapmaları ve değişkenlerin aralarındaki Pearson korelasyon katsayıları Tablo 4'te görülmektedir. Ortalama değeri en yüksek, standart sapması en düşük olan faktörün doğal duygular olduğu gözlemlenmektedir. Birey örgüt uyumu ile yüzeysel davranış ilişkisi dışında tüm ilişkilerin çeşitli seviyelerde anlamlı ilişkiler içerisinde olduğu görülmektedir. Birey örgüt uyumu hem derinden davranış ( $\mathrm{r}=, 612)$, hem de doğal duygular boyutu ile (r=,307) pozitif yönlü anlamlı ilişkilere sahiptir. Yüzeysel davranış ile derinden davranış $(\mathrm{r}=-, 228)$ ve doğal duygular $(\mathrm{r}=-, 373)$ arasında ise negatif yönlü anlamlı ilişkiler tespit edilmiştir. En güçlü ilişki ise derinden davranış ve doğal duygular faktörleri arasındadır $(r=, 810)$.

Tablo 4. Korelasyon Analizi Sonuçları

\begin{tabular}{lcccccc}
\hline & Ort. & S.S. & $\mathbf{1}$ & $\mathbf{2}$ & $\mathbf{3}$ & $\mathbf{4}$ \\
\cline { 2 - 7 } 1.Birey Örgüt Uyumu & 2,49 & 1,12 & 1 & & & \\
2.Yüzeysel Davranış & 2,36 & 1,04 &,- 009 & 1 & & \\
3.Derinden Davranış & 3,16 & 1,29 &, $612^{* *}$ &,$- 228^{* *}$ & 1 & \\
4.Doğal Duygular & 3,65 &, 96 &, $307^{* *}$ &,$- 373^{* *}$ &, $810^{* *}$ & 1 \\
\hline
\end{tabular}

$N=355 ; * * p<0.01$

\subsection{Regresyon Analizi}

Birey örgüt uyumunun duygusal emek boyutları üzerindeki etkilerinin belirlenmesi amacıyla üç farklı basit doğrusal regresyon analizi yapılmıştır. Regresyon analizinden elde edilen sonuçlar Tablo 5'te gösterilmiş̧tir. Model 1'de birey örgüt uyumunun yüzeysel davranış üzerindeki etkisi incelenmiştir ve birey örgüt uyumunun yüzeysel davranışı anlamlı bir şekilde etkilemediği bulgulanmıştır. Buradan hareketle çalışmanın ilk hipotezi Hipotez 1 kabul edilmemiştir $(\beta=-, 009 ; \mathrm{p}=, 873)$.

Tablo 5. Regresyon Analizi Sonuçları

\begin{tabular}{llccccc}
\hline & & Std. $\boldsymbol{\beta}$ & $\boldsymbol{t}$ & Sig. & Düz. $\boldsymbol{R}^{2}$ & $\boldsymbol{F}$ \\
Model 1 & Birey Örgüt Uyumu $\rightarrow$ Yüzeysel Davranış &,- 009 &,- 160 &, 873 &,- 003 &,- 026 \\
Model 2 & Birey Örgüt Uyumu $\rightarrow$ Derinden Davrantş &, 612 & 14,545 &, 000 &, 373 & 211,558 \\
Model 3 & Birey Örgüt Uyumu $\rightarrow$ Doğal Duygular &, 307 & 6,064 &, 000 &, 092 & 36,770 \\
\hline
\end{tabular}

Model 2'de birey örgüt uyumunun derinden davranış üzerindeki etkisi incelenmiştir. Elde edile bulgulara göre birey örgüt uyumu derinden davranışı olumlu yönde anlamlı bir şekilde etkilemektedir $(\beta=0,612 ; p<0.01)$. Buna göre birey örgüt uyumu bir birim arttığında, derinden davranış 0,612 ( $\beta$ ) birim artmaktadır. Model 2'nin düzeltilmiş $\mathrm{R}^{2}$ değeri ,373'tür. Yani birey örgüt uyumu, derinden davranıştaki değişimin \% 37'sinden sorumludur. Bu sonuçlar çalışmada öne sürülen Hipotez 2 'nin kabul edildiğini göstermektedir. Son olarak Model 3 'te doğal duyguların birey örgüt uyumundan nasıl etkilendiği analiz edilmiştir. Elde edilen sonuçlara göre birey örgüt uyumu doğal duyguları pozitif yönde anlamlı bir şekilde etkilemektedir $(\beta=0,307 ; \mathrm{p}<0.01)$. Yani birey örgüt uyumu bir birim arttığında, doğal duygular 0,307 $(\beta)$ birim artmaktadır. Dolayısıyla çalışmada geliştirilen Hipotez 3 kabul edilmiştir. Model 3'ün düzeltilmiş $\mathrm{R}^{2}$ değeri ,092'dir. Yani birey örgüt uyumu, doğal duygulardaki değişimin yaklaşık olarak \% 1'inden sorumludur.

\section{SONUÇ VE DEĞERLENDİRME}

Yönetim biliminin tarihi incelendiğinde, yönetim biliminin gelişmeye başladığı ilk y1llarda bilimsel yönetim ilkeleri çerçevesinde çalışanların duygularını işe karıştırmamaları ve duygularını bastırmaları gerektiği ifade edilmekteydi. Bu bakış açısıyla çalışanlar işe gelirken duygularını dışarıda bırakmalı ve işyerinde adeta programlanmış bir robot gibi hareket etmeliydi. Fakat ilerleyen yıllarda insan duygularının ihmal edilmemesi gerektiği ve hatta duyguların kontrolü ile çalışan verimliliğinin ve dolayısıyla işletme performansının artabileceği fark edildi. Özellikle iletişimin birçok unsurunun kullanıldığ1 ve müşteri ilişkilerinin yoğun olduğu hizmet sektöründe duygu yönetiminin daha önemli olduğu sonucu ortaya çıktı. Bu önemine binaen birçok sektörde olduğu gibi sağlık sektörü çalışanları üzerinde de ciddi araştırmalar yapıldı. Özellikle hemşirelerin duygusal düzenleme yapabilmeleri ve hastalar üzerinde olumlu etkiler bırakmaları veya en azından olumsuz etkiler bırakmamaları yönünde birçok araştırma yapılmıştır (örn. Altuntaş ve Altun, 2015; Hong ve Lee, 2016; 
Liang vd., 2016; Tunç vd., 2014; Yoon ve Kim, 2013). His ve duyguları organizasyonun istediği yönde planlama ve kontrol etme olarak ifade edilebilecek duygusal emeği etkileyen faktörleri ortaya çıkarmak, birçok işkolunda olduğu gibi sağlık hizmetlerinin hedef kitlesini memnun etmede önemli rol oynayacaktır. Buradan hareketle bu çalışmada çalışan ile örgüt uyumunun çalışanlardan talep edilen duygusal emeği ne yönde etkilediği incelenmiştir. $\mathrm{Bu}$ araştırma, örgütsel değerler ile kişisel değerler uyumlaştırıldığında çalışanların örgüt ve müşteriler yararına önemli ölçüde duygusal çaba içerisine gireceği varsayımıyla yapılmıştır. Bazı kısıtlara rağmen çalışmadan elde edilen sonuçların ilgili alanda çalışan bilimsel araştırmacılar ile hastane çalışan ve yöneticilerine hedef kitleyi tatmin etme yolunda önemli ipuçları sunacağı düşünülmektedir.

Araştırmadan elde edilen ilk bulguya göre birey örgüt uyumu yüzeysel davranış eğilimlerini herhangi bir şekilde etkilememektedir. Yani birey örgüt uyumu arttığında çalışanların daha az sahte davranışlar sergileyeceğine yönelik herhangi bir kanıt bulunmamaktadır. Yapmacık davranan bireylerin örgütsel değerlere uyum sağlayamamaktan ziyade daha farklı nedenlerle yüzeysel davrandığı düşünülmektedir. Grandey (2000)'e göre duyguların dışarıdan yönetildiği yüzeysel davranış, duyguların içerden yönetildiği derinden davranışa göre daha maliyetlidir ve yüzeysel davranışın olumlu sonuçlar doğurma ihtimali daha azdır. Dolayısıyla çalışanların neden yüzeysel rol yaptığına yönelik daha derin araştırmalar yapılmalıdır. Sosyal desteğin zayıflığı, özgüven düşüklüğü, çalışanlara gerekli eğitimlerin verilmemesi, personel seçmenin bilinçli yapılmaması gibi nedenlerin örgütlerde yüzeysel davranışları arttıracağını ifade eden çalışmalar bulunmaktadır (Hsieh, 2014; Hsieh vd., 2016).

Araştırmadan elde edilen bir diğer sonuç, derinden rol yapmanın birey örgüt uyumundan olumlu yönde etkilendiği yönündedir. İnsan duyguları kişisel faktörlerin yanında birçok dışsal faktörden olumlu veya olumsuz yönde etkilenmektedir. Dış çevresel faktörlerde önemli bir yeri olan örgüt ile ilişkilerin bireylerin duygularını nasıl şekillendirdiği bu araştırma sonucunda görülmektedir. Örgüt ile kendisinin birbirini tamamladığını ve ortak değerleri yaşatmak için örgüt ile bir araya geldiğini düşünen çalışanların, iş ortamında birçok olumlu sonuçlar doğuran derinden davranışları sergilemeye yöneldiği ortaya konmuştur. Yani çalışanların fiziksel duygu gösterimleri ile içsel duygularının aynılığını ortaya koyan derinden davranışlarının artışı, çalışan örgüt uyumunun sağlanmasıyla kolaylaşacaktır. Nitekim Sutarjo (2011:227) bireylerin ve örgütlerin sahip olduğu ortak etkili iş değerlerinin his ve duygularla ilişkili olduğunu, bunun da diğerleri ile olumlu ilişkiler kurma anlamına geleceğini belirtmektedir. Yani kişi ile örgüt arasındaki çalışanlarca algılanan uyum başkalarını, örneğin müşterileri anlamayı ifade eden derinden davranışları tetikleyebilmektedir. Bu noktada yöneticilere önerilen, kişi örgüt uyumunu sağlayacak kararların işletmenin kurulma aşamasında alınmaya başlanması ve süreç içerisinde optimum uyum noktasına ulaştıracak uygulamaların yapılmasıdır.

Bireyler samimi duygularını ifade ederken yüzeysel ve derinden davranıştaki kadar duygusal emek harcamamaktadırlar. Dolayısıyla çalışanların duygularının samimi bir şekilde müşterilere aktarılmasının sağlanması, bireyleri özellikle psikolojik olarak yormayacak ve birçok olumlu sonucu beraberinde getirebilecektir. Birey örgüt uyumunun çalışanların samimi duygu ve davranışlarını etkilemesi, bu uygulamalı çalışmadan elde edilen önemli bir diğer sonuçtur. Samimi duyguların ifade edilmesinin aslında bir pazarlama stratejisi olması gerektiği düşünülmektedir. Çünkü çalışanlar, örgütün hedef kitlesi (müşteri, hasta, yolcu, öğrenci vb.) tarafından bilinçli veya yarı bilinçli bir şekilde samimiyet testine sokulmaktadır. Bu testi geçebilen çalışanlar ve örgütler müşteriler nezdinde olumlu bir imaja sahip olmaktadır. Fakat çalışanın yapmacık davrandığını, kendisine karşı doğal ve samimi olmadığını hisseden hedef kitle, kurumdan olumsuz duygularla ayrılacaktır (Mengenci, 2015: 128). Bu açıdan bakıldığında samimiyeti arttıran birey örgüt uyumunun sağlanmasının hem pazarlama hem de insan kaynakları birimlerinin temel görevlerinden biri olduğu görülmektedir. Diğer taraftan bireyler çevrelerine uyum sağlayabildiği ölçüde doğal davranmaktadırlar. Örneğin içinde bulunduğu sosyal, fiziksel ve kültürel ortama uyum sağlayabilen bir kişi sahte davranışlar içine girmeyecek bilakis daha doğal hareket edecektir. Çünkü uyum içinde hareket edilen bir ortamda samimiyetsiz davranma, uyum sağladığımız parçalara saygısızlık olarak algılanabilecektir. Benzer şekilde, samimi davranmama birçok kültürde ikiyüzlülük, riyakarlık, aldatma gibi olumsuz kavramlarla ilişkilendirilebilmektedir. Çalışanlarında bu olumsuz özellikleri görmek istemeyen insan kaynakları ve pazarlama yöneticilerinin birey örgüt uyumuna önem vermeleri gerektiği görülmektedir. Özetle, çalışan ile işletme değerleri arasında sağlanacak ahenk ve uyum, çalışanların samimi davranmalarının önünü açacaktır.

Genel olarak çalışmadan elde edilen sonuçlar yorumlandığında, müşteriye sürekli derin ve doğal davranışlarla hizmet götürmesi beklenen çalışanın (Mengenci, 2015: 128) örgütüyle uyumunun sağlanması gerektiği 
görülmektedir. Böylece çalışanlar tarafindan ortaya konan duygusal çabanın somut sonuçlar doğurabileceği görülmektedir.

\subsection{Araştırma Kısıtları ve Gelecek Araştırmalar için Öneriler}

Doğal ve samimi davranma birçok olumlu sonuçla ilişkilendirilirken bazı durumlarda ise olumlu sonuçlar doğurmayabilir. Örneğin Wong ve Wang (2009) samimiyetin yanlış yorumlanabilecek mesajlar üretebileceği ve taraflar arasında çatışmaların yaşanabileceğini ifade etmektedirler. Bunun yerine müşterilerle iletişimde duygu gösterimlerinin çalışanlarca kontrol edilmesini önermektedirler. Çalışanların içlerinden geçen her duyguyu dışarıya yansıtmaları çok uygun olmayabilir (Morris ve Feldman, 1997; Zapf ve Holz, 2006). Örneğin bir çalışanın o anki aşırı mutluluğunu veya kızgınlığını hedef kitleye doğal bir şekilde yansıtması ilgili kişilerde olumsuz etkiler bırakabilir. Buradan hareketle birey ile örgüt arasında sağlanacak aşırı uyumun bireylerin gereğinden fazla samimi davranmasını sağlayabileceğinden, uyumun sınırlarının belirlenmesi gerektiği sonucu ortaya çıkmaktadır.

Gelecek araştırmaların, kültürel özelliklerin farklı olduğu bölgeler veya ülkelerde yapılması araştırma sonuçlarının güncellenmesini sağlayabilecektir. Sohn vd. (2016) duygusal emeği anlamak için farklı kültürde araştırmaların yapılmasının daha sağlıklı olacağını ifade etmektedirler çünkü çalışanların duygusal tepkileri gösteriş biçimi milliyete, etnik kökene, dine, mesleğe, ekonomik şartlar vb. durumlara göre değişebilmektedir. Örneğin bazı kültürlerde gerçek duyguları ifade etmeye, açık sözlülüğe değer verilirken bazı kültürlerde her şeye rağmen karşı tarafa saygı duymaya, içten gelen duyguları bastırmaya ve kontrol etmeye daha fazla önem verilebilmektedir. Benzer şekilde duygu gösteriminin önemli bir unsuru olan yüz ifadelerinin içerdiği anlamların kültürden kültüre değişebildiği ifade edilmektedir (Oğuz ve Özkul, 2016).

Bu çalışmada duygusal emek kavramı sadece birey örgüt uyumu çerçevesinde değerlendirilmiştir. Gelecek araştırmalarda araştırma modeline daha farklı değişkenlerin eklenmesi, modelin anlamlılı̆̆ını arttırabilecektir.

\section{KAYNAKÇA}

Afsar, B. ve Badir, Y. F. (2016). "Person-Organization Fit, Perceived Organizational Support, and Organizational Citizenship Behavior: The Role Of Job Embeddedness", Journal of Human Resources in Hospitality \& Tourism, 15(3), 252-278.

Akbaş, T. T. (2010). “Örgütsel Etik İklim, Birey-Örgüt Uyumu, Örgütsel Bağlılık ve Örgütsel Vatandaşlık Davranışı İlişkisi; Görgül Bir Araştırma”, Doktora Tezi, Gazi Üniversitesi Sosyal Bilimler Enstitüsü, Ankara.

Altuntaş, S. ve Altun, Ö. Ş. (2015). "Hemşirelerin Duygusal Emek Davranışları ve Tükenmişlik Düzeyleri Arasındaki İlişki”, Sağlık ve Hemşirelik Yönetimi Dergisi, 1(2), 37-43.

Ashforth, B. E. ve Mael, F. (1989). "Social Identity Theory and The Organization”, Academy of Management Review, 14, 20-39.

Ashforth, B.E. ve Humphrey R.H. (1993). "Emotional Labor in Service Roles: The Influence of Identity", Academy of Management Review, 18(1), 88-115.

Autry, C.W. ve Wheeler, A.R. (2005). "Post-hire Human Resource Management Practices and Personorganization Fit: A Study of Blue-collar Employees”, Journal of Managerial Issues, 17(1), 58-75.

Babakus, E., Yavaş, U. ve Ashill, N.J. (2009). "The Role of Customer Orientation as a Moderator of the JobDemand-Burnout-Performance Relationship: A Surface-Level Trait Perspective”, Journal of Retailing, 85 (4), 480-492.

Basım, H. N. ve Beğenirbaş, M. (2012). "Çalışma Yaşamında Duygusal Emek: Bir Ölçek Uyarlama Çalışması”, Yönetim ve Ekonomi: Celal Bayar Üniversitesi İktisadi ve İdari Bilimler Fakültesi Dergisi, 19(1), 77-90.

Beğenirbaş, M. ve Turgut, E. (2014). "İş Yaşamında Çalışanların Duygusal Emeklerinin Örgütsel Sinizme Etkileri: Bankacılık Sektöründe Bir Araştırma”, Çankırı Karatekin Üniversitesi İktisadi ve İdari Bilimler Fakültesi Dergisi, 4(2), 223-246. 
Bowen, D. E., Ledford, G. E., Jr. ve Nathan, B. R. (1991). "Hiring For The Organization, Not The Job", The Executive, 5(4), 35-51.

Brotheridge, C. M. ve Grandey, A. A. (2002). "Emotional Labor and Burnout: Comparing Two Perspectives of "People Work." Journal of Vocational Behavior, 60(1), 17-39.

Carless, S.A. (2005). "Person-Job Fit Versus Person-Organization Fit As Predictors of Organizational Attraction and Job Acceptance Intentions: A Longitudinal Study", Journal of Occupational and Organizational Psychology 78(3), 411-429.

Castka, P., Bamber, C.J., Sharp, J.M. ve Belohoubek, P. (2001). "Factors Affecting Successful Implementation of High Performance Teams", Team Performance Management: An International Journal, 7(7/8), 123134.

Chatman, J. A. (1989). "Improving Interactional Organizational Research: A Model of Person- Organization Fit", Academy Of Management Review, 14(3), 339-340.

Cheng, Z. (2014). "Research On Recruitment Model Based On Person-Organization Fit", International Journal of Business Administration, 5(2), 126-131.

Connellan, T. ve Zemke, R. (1993). Sustaining Knock Your Socks Off Service, New York: AMACOM.

Conrad, C. ve Witte, K. (1994). "Is Emotional Expression Repression Oppression? Myths Of Organizational Affective Regulation”. In S. Deetz (Ed.), Communication yearbook (Vol. 17, pp. 417-428), Newbury Park, CA: Sage.

Çanakkale Valiliği (2016), Sayılarla Çanakkale, Çanakkale Valiliği İl Planlama ve Koordinasyon Müdürlüğü, http://www.canakkale.gov.tr/sayilarla-canakkale (Erişim Tarihi: 21 Şubat 2016).

de Lara, P. Z. M. (2008). "Should Faith and Hope Be Included in The Employees' Agenda? Linking PO Fit and Citizenship Behavior”, Journal of Managerial Psychology, 23(1), 73-88.

Deng, H., Wu, C.-H., Leung, K. ve Guan, Y. (2015). "Depletion From Self-Regulation: A Resource-Based Account of The Effect of Value Incongruence", Personnel Psychology, 69, 431-465.

Diefendorff, J. M., Croyle, M. H. ve Gosserand, R. H. (2005). "The Dimensionality and Antecedents of Emotional Labor Strategies”, Journal of Vocational Behavior, 66(2), 339-357.

Durgut, M. ve Kahya, C. (2015). "Duygusal Emek ve Örgütsel Sessizlik Arasındaki İlişki: Kamu İç Denetçileri Üzerinde Örnek Bir Uygulama”, Yönetim ve Ekonomi Araştırmaları Dergisi, 13(1), 348-364.

Fineman, S. (Ed.). (1993). Emotion in Organizations, London: Sage.

Gibson, J.L., Ivancevich, J.M., Donelly, J.H. ve Konopaske, R. (2003). “Organizations: Behavior, Structure, Processes", 11th ed., McHraw-Hill/Irwin, New York.

Goodman, S. ve Svyantek, D. J. (1999). "Person-Organization Fit and Contextual Performance: Do Shared Values Matter?", Journal of Vocational Behavior, 55(2), 254-275.

Grandey, A. A. (2000). "Emotional Regulation in The Workplace: A New Way to Conceptualize Emotional Labor", Journal of Occupational Health Psychology, 5(1), 95-110.

Grandey, A. (2003). "When The Show Must Go On: Surface Acting and Deep Acting as Determinants of Emotional Exhaustion and Peer-rated Service Delivery", Academy of Management Journal, 46(1), 8696.

Gülova, A. A., Palamutçuoğlu, B. T. ve Palamutçuoğlu, A. T. (2013). "Duygusal Emek İle İşe Bağlılık Arasındaki İlişkide Amir Desteğinin Rolü: Üniversitede Öğrenci İşleri Personeline Yönelik Bir Araştırma”, Dokuz Eylül Üniversitesi İktisadi ve İdari Bilimler Fakültesi Dergisi, 28(2), 41-74.

Hair, J. F. Jr., Bush, R. P. ve Ortinau, D. J. (2003). Marketing Research: Within a Changing Information Environment, The McGraw-Hill/Irwin, Second Editon.

Hochschild, A. (1989). The Second Shift: Working Parents and The Revolution at Home, New York, NY: Viking. 
Hochschild, A. R. (1983). The Managed Heart: The Commercialization of Feeling, Berkeley: University of California Press.

Hoffman, B. J. ve Woehr, D. J. (2006). "A Quantitative Review Of The Relationship Between PersonOrganization Fit and Behavioral Outcomes", Journal of Vocational Behavior, 68(3), 389-399.

Hong, E. ve Lee, Y. S. (2016). "The Mediating Effect of Emotional Intelligence Between Emotional Labour, Job Stress, Burnout and Nurses' Turnover Intention”, International Journal of Nursing Practice, 22(6), 625632.

Hsieh, C. W., Hsieh, J. Y. ve Huang, I. Y. F. (2016). "Self-Efficacy as a Mediator and Moderator Between Emotional Labor and Job Satisfaction: A Case Study of Public Service Employees in Taiwan”, Public Performance \& Management Review, 40(1), 71-96.

Hsieh, C.W. (2014). "Burnout Among Public Service Workers: The Role of Emotional Labor Requirements and Job Resources”, Review of Public Personnel Administration, 34(4), 379-402.

Karaatlı, M. (2006). Verilerin Düzenlenmesi ve Gösterimi, SPSS Uygulamalı Çok Değişkenli İstatistik Teknikleri, (Ed.: Şeref Kalaycı), İkinci Baskı, Ankara: Asil Yayın Dağıtım.

Kızanlıklı, M. ve Ünlüönen, K. (2016). “Otel İşletmelerinde Davranış Kuralı Algısı ve İş Doyumunun Duygusal Emek Davranışı Üzerindeki Etkisinin Belirlenmesi”, Ege Akademik Bakış, 16 (3), 503-518.

Ko, C. H. ve Jeng, S. H. (2016). "Exploring The Effects Of Emotional Labor in The Hotel Industry", The International Journal of Organizational Innovation, 9(2), 158-167.

Kristof, A.L. (1996). "Person-Organization Fit : An Integrative Review Of its Conceptualizations, Measurement and Implications", Journal of Personnel Psychology, 49(1), 1-49.

Kristof-Brown, A.L., Zimmerman, R.D. ve Johnson, E.,C. (2005). "Consequences of Individuals"e Fit at Work: A Metaanalysis of Person-Job, Person-Organization, Person-Group, and Person-Supervisor Fit”, Journal of Personnel Psychology, 58(2), 281-342.

Kruml, S. M. ve Geddes, D. (2000). "Exploring The Dimensions Of Emotional Labor the Heart of Hochschild's Work", Management Communication Quarterly, 14(1), 8-49.

Kunnan, A. J. (1998). “An Introduction to Structural Equation Modelling for Language Assessment Research”, Language Testing, 15(3), 295-332.

Lauver K.J. ve Kristof-Brown, A. (2001). "Distinguishing Between Employees' Perceptions of Person-Job and Person-Organization Fit”, Journal of Vocational Behavior, 59(3), 454-470.

Lee, D., Hung, L. ve Huang, S. (2012). "Does Job Enjoyment and Organizational Support Affect Emotional Labor?”, İşletme Araştırmaları Dergisi, 4(2), 5-29.

Li, J. (2006). "The Interactions Between Person-Organization Fit and Leadership Styles in Asian Firms, An Empirical Testing", The International Journal of Human Resource Management, 17(10), 1689-1706.

Liang, H. Y., Tang, F. I., Wang, T. F., Lin, K. C. ve Yu, S. (2016). "Nurse Characteristics, Leadership, Safety Climate, Emotional Labour and Intention to Stay For Nurses: A Structural Equation Modelling Approach", Journal of Advanced Nursing, 72(12), 3068-3080.

Meglino, B. M., Ravlin, E. C. ve Adkins, C. L. (1989). “A Work Values Approach to Corporate Culture: A Field Test of The Value Congruence Process and its Relationship to Individual Outcomes", Journal of Applied Psychology, 74(3), 424-432.

Meier, K. J., Mastracci, S. H. ve Wilson, K. (2006). "Gender And Emotional Labor in Public Organizations: An Empirical Examination of The Link to Performance”, Public Administration Review, 66(6), 899-909.

Mengenci, C. (2015). “İş Tatmini, Duygusal Emek ve Tükenmişlik İlişkilerinin Belirlenmesi”, Ege Akademik Bakış, 15 (1), 127-139.

Mesmer-Magnus, J.R., Dechurch, L.A., Wax, A. ve Anderson, K.T. (2011). "Dissonance Matters Meta-Analytic Examination of the Consequences of Emotional Labor", Academy of Management Annual Meeting Proceedings, Janurary 2011. 
Mishra, S. K., Bhatnagar, D., D’Cruz, P. ve Noronha, E. (2012). “Linkage Between Perceived External Prestige and Emotional Labor: Mediation Effect of Organizational Identification Among Pharmaceutical Representatives in India", Journal of World Business, 47(2), 204-212.

Morris, J. A. ve Feldman, D. C. (1997). "Managing Emotions in The Workplace”, Journal of Managerial Issues, 9(3), 257-275.

Netemeyer, R. G., Boles, J. S., McKee, D. O. ve McMurrian, R. (1997). “An Investigation Into The Antecedents of Organizational Citizenship Behaviors in A Personal Selling Context”, The Journal of Marketing, 61, 85-98.

Oğuz, H. ve Özkul, M. (2016). "Duygusal Emek Sürecine Yön Veren Sosyolojik Faktörler Üzerine Bir Araştırma: Batı Akdeniz Uygulaması”, Süleyman Demirel Üniversitesi Vizyoner Dergisi, 7 (16), 130 154.

Ostroff, C., Shin, Y. ve Kinicki, A. J. (2005). "Multiple Perspectives of Congruence: Relationships Between Value Congruence and Employee Attitudes", Journal of Organizational Behavior, 26(6), 591-623.

Öz, E.Ü. (2007). Duygusal Emek Davranışlarının Çalışanların İş Sonuçlarına Etkisi, Beta Basım Yayım Dağıtım A. Ş., İstanbul.

Öztürk, E. (2006). Çoklu Doğrusal Regresyon Modeli, SPSS Uygulamalı Çok Değişkenli İstatistik Teknikleri, (Ed.: Şeref Kalayc1), Ankara: Asil Yayın Dağıtım.

Pekdemir, I., Koçoğlu, M. ve Gürkan, G. Ç. (2013). "Birey-Örgüt Uyumunun Açıkça Konuşma Davranış1 Üzerindeki Etkisinde Algılanan Yönetici Desteğinin Aracılık Rolü: MBA Öğrencilerine Yönelik Bir Araştırma”, İ.Ü. İşletme Fakültesi İşletme İktisadı Enstitüsü Yönetim Dergisi, 24(75), 83-104.

Pierce, J. L. ve Gardner, D. G. (2004). "Self-Esteem Within The Work and Organizational Context: A Review Of The Organization-Based Self-Esteem Literatüre", Journal of Management, 30(5), 591-622.

Polatcı, S. ve Özyer, K. (2015). "Duygusal Emek Stratejilerinin Duygusal Zekânın Tükenmişliğe Etkisindeki Aracılık Rolü’, Abant İzzet Baysal Üniversitesi Sosyal Bilimler Enstitüsü Dergisi, 15(3), 131-156.

Price, L. L., Arnould, E. J. ve Tiemey, P. (1995). "Going to Extremes: Managing Service Encounters and Assessing Provider Performance", Journal of Marketing, 59(2), 83-97.

Rayner, J. ve Espinoza, D. E. (2015). "Emotional Labour Under Public Management Reform: An Exploratory Study of School Teachers in England", The International Journal of Human Resource Management, 27(19), 2254-2274.

Roh, C. Y., Moon, M. J., Yang, S. B. ve Jung, K. (2016). “Linking Emotional Labor, Public Service Motivation, and Job Satisfaction: Social Workers in Health Care Settings", Social Work in Public Health, 31(2), 43 57.

Sathe, V. (1985). How to Decipher and Change Corporate Culture, In Gaining Control of the Corporate Culture, eds. R.H. Kilmann, M.J. Saxton, R. Serpa and Associates, Jossey-Bass Inc., San Fransisco.

Schaubroeck, J. ve Jones, J. R. (2000). "Antecedents of Workplace Emotional Labor Dimensions and Moderators of Their Effects On Physical Symptoms”, Journal of Organizational Behavior, 21(2), 163183.

Schneider, B., Goldstiein, H. W. ve Smith, D. B. (1995). "The ASA Framework: An Update", Personnel Psychology, 48(4), 747-773.

Schneider, B. (1987). “The People Make The Place”, Personnel Psychology, 40, 437-453.

Scott, B.A., Barnes, C.M. ve Wagner, D.T. (2012). "Chameleonic or Consistent? A Multilevel Investigation of Emotional Labor Variability and Self-Monitoring”, Academy of Management Journal, 55(4), 905-926.

Scott, B. A. ve Barnes, C. M. (2011). “A Multilevel Field Investigation of Emotional Labor Affect, Work Withdrawal, And Gender”, Academy of Management Journal, 54(1), 116-136.

Seeman, M. (1991). Alienation and Anomie. In J. Robinson, P. Shaver, \& L. Wrightsman (Eds.), Measures of Personality and Social Psychological Attitudes (pp. 291-295). San Diego, CA: Academic Press. 
Sharrad, H. (1992). "Feeling the Strain: Job Stress and Satisfaction of Direct-Care Staff in The Mental Handicap Service", British Journal of Mental Subnormality, 38(74), 32-38.

Shuler, S. ve Sypher, B. D. (2000). "Seeking Emotional Labor: When Managing The Heart Enhances The Work Experience”, Management Communication Quarterly, 14(1), 751-789.

Silverthorne, C. (2004). "The Impact of Organizational Culture and Person-Organization Fit On Organizational Commitment and Job Satisfaction in Taiwan”, Leadership \& Organization Development Journal, 25(7), 592-599.

Sipahi, G. A. ve Kesen, M. (2016). "Beş Yıldızlı Otel İşletmelerinde Örgütsel Bağlılığın Birey Örgüt Uyumu ve İşten Ayrılma Niyeti Üzerindeki Etkisi”, Eurasian Academy of Sciences Eurasian Business \& Economics Journal, S2, 340-352.

Smith, M.R., Rasmussen, J.L., Mills, M.J., Wefald, A.J. ve Downey, R.G. (2012). "Stress and Performance: Do Service Orientation and Emotional Energy Moderate The Relationship?", Journal of Occupational Health Psychology, 17 (1), 116-128.

Sohn, H. K., Lee, T. J. ve Yoon, Y. S. (2016). "Emotional Labor and Burnout: Comparison Between the Countries of Japan and Korea", Journal of Travel \& Tourism Marketing, 33(5), 597-612.

Strickland,W. (1992). "Institutional Emotional Norms and Role Satisfaction: Examination of A Career Wife Population”, Sex Roles, 26, 423-439.

Sutarjo, A. (2011). "Ten Ways Of Managing Person-Organization Fit (PO Fit) Effectively: A Literature Study", International Journal of Business and Social Science, 2(21), 226-233.

Tezbaşaran, A. A.(1996). Likert Tipi Ölçek Geliştirme Kılavuzu, Ankara: Türk Psikologlar Derneği Yayınları.

Thomassen, T. (2012). 'Newcomers' Person-Environment Fit: The Moderating Role of Emotion Regulation Strategies”, Master's Thesis Human Resource Studies, Tilburg University.

Tolich, M. (1993). “Alienating and Liberating Emotions At Work: Supermarket Clerks' Performance of Customer Service”, Journal of Contemporary Ethnography, 22(3), 361-381.

Tunç, P., Gitmez, A. ve Krespi Boothby, M. R. (2014). "Yoğun Bakım ve Yataklı Servis Hemşirelerinde Duygusal Emek Stratejilerinin Empatik Eğilim Açısından İncelenmesi”, Anadolu Psikiyatri Dergisi, 15, 45-54.

Turner, J. C., Hogg, M. A., Oakes, P. J., Reicher, S. D. ve Wetherell, M. (1987). Rediscovering the Social Group: A Self-Categorization Theory. Oxford, UK: Blackwell.

Van Knippenberg, D. ve Sleebos, E. (2006). “Organizational Identification Versus Organizational Commitment: Self-Definition, Social Exchange And Job Attitudes”, Journal of Organizational Behavior, 27(5), 571584.

Van Vianen, A.E.M., De Pater, I.E. ve Van Dijk, F. (2007). "Work Value Fit and Turnover Intention: SameSource Or Different-Source Fit”, Journal of Managerial Psychology, 22(2), 188-202.

Verquer, M.L., Beehr, T.A ve Wagner, S.H. (2003). "A Meta-Analysis Of Relations Between PersonOrganization Fit and Work Attitudes", Journal of Vocational Behavior, 63(3), 473-489.

Vilela, B. B., Gonzales, J. A. V. ve Ferrin, P. F. (2008). "Person-Organization Fit, OCB and Performance Appraisal: Evidence From Matched Supervisor-Salesperson Data Set in A Spanish Context", Industrial Marketing Management, 37(8), 1005-1019.

Wang, M. L. ve Chang, S. C. (2016). "The Impact of Job Involvement on Emotional Labor to CustomerOriented Behavior: An Empirical Study of Hospital Nurses”, Journal of Nursing Research, 24(2), 153 162.

Wharton, A. (1993). "The Affective Consequences of Service Work”, Work and Occupations, 20, 205-232.

Wong, J. Y. ve Wang, C. H. (2009). "Emotional Labor of The Tour Leaders: An Exploratory Study", Tourism Management, 30(2), 249-259. 
Xanthopoulou, D., Bakker, A. B., Demerouti, E. ve Schaufeli, W. B. (2007). "The Role Of Personal Resources In The Job Demands-Resources Model”, International Journal of Stress Management, 14(2), 121-141.

Yazıcıŏ̆lu, Y. ve Erdoğan, S. (2004). SPSS Uygulamalı Bilimsel Araştırma Yöntemleri. Ankara: Detay Yayıncilık.

Yoon, S. L. ve Kim, J. H. (2013). “Job-Related Stress, Emotional Labor, and Depressive Symptoms Among Korean Nurses”, Journal of Nursing Scholarship, 45(2), 169-176.

Yücel, İ. ve Çetinkaya, B. (2016). "Birey-Örgüt Uyumu ile Örgütsel Bağlılık Arasındaki İlişkide Cinsiyetin Rolü: Kayseri Örneği”, Aksaray Üniversitesi İktisadi ve İdari Bilimler Fakültesi Dergisi, 8(3), 17-30.

Zapf, D. ve Holz, M. (2006). "On the Positive and Negative Effects of Emotion Work in Organizations", European Journal of Work and Organizational Psychology, 15(1), 1-28.

Zeng, Y., Chen, X. ve Chen, Y. (2014). Impact of Emotional Intelligence on Emotional Labor Strategy: the Mediating Effects of General Self-Efficacy and Organizational Identification. In Proceedings of International Conference on Computer Science and Service System (CSSS 2014) (pp. 207-210). 